\title{
Milk Proteins - Analytical Methods
}

Didier Dupont ${ }^{\mathrm{a}}$, Thomas Croguennec ${ }^{\mathrm{a}}$, and Sylvie Pochet ${ }^{\mathrm{b}},{ }^{\mathrm{a}}$ STLO, INRA-Agrocampus Ouest, Rennes, France; and ${ }^{\mathrm{b}}$ URTAL, INRA, Poligny, France

(C) 2018 Elsevier Inc. All rights reserved.

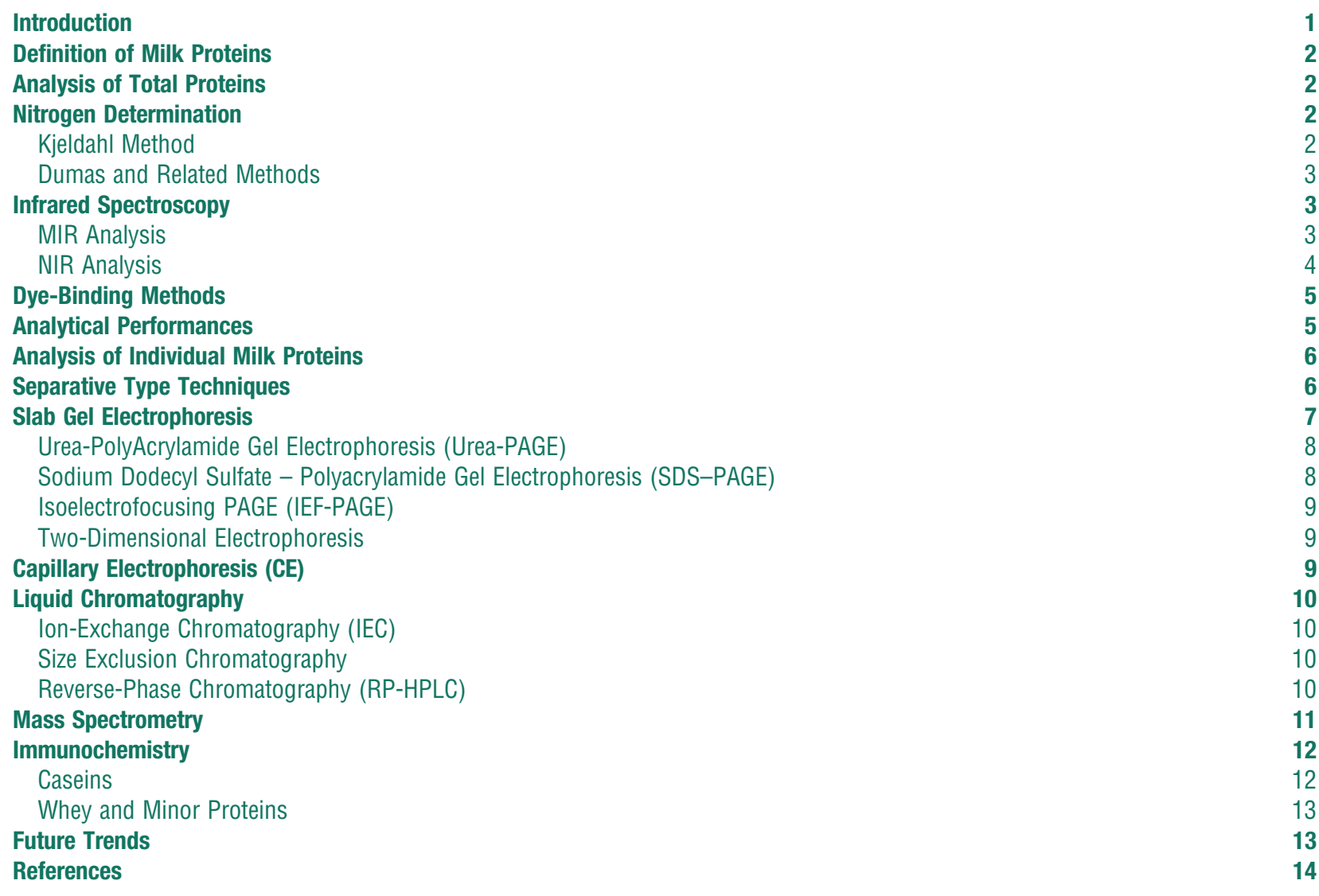

\section{Introduction}

Milk contains certainly more than 100 different proteins. The major part of them are classified into three nitrogen fractions: caseins $(\mathrm{CN})$ which are the most abundant $(78 \%)$ and consist in four individual proteins ( $\alpha \mathrm{s}_{1^{-}}, \alpha \mathrm{s}_{2^{-}}, \beta$ - and $\kappa$-casein), serum or whey proteins $(17 \%)$, which include $\alpha$-lactalbumin $(\alpha$-la), $\beta$-lactoglobulin $(\beta$-lg), blood serum albumin (BSA) and immunoglobulins (Ig); and the non-protein nitrogen (NPN) fraction (5\%). Milk proteins also include milk fat globule membrane proteins i.e. more than 120 proteins representing $1 \%-2 \%$ of total milk proteins (Reinhardt and Lippolis, 2006) and more than 70 enzymes (O'Mahony et al., 2013) and hormones. In addition, the caseins and whey proteins are present as at least 50 identified genetic variants, 12 being predominantly studied in analytical procedures. Caseins also possess different degrees of glycosylation ( $\kappa-\mathrm{CN})$ and phosphorylation $\left(\alpha \mathrm{s}_{1-}, \alpha \mathrm{s}_{2-}\right.$ and $\left.\beta-\mathrm{CN}\right)$. They may also be partly hydrolyzed at milking, with the formation of breakdown products. Genetic, environmental factors and cattle management explain qualitative and quantitative variability of the milk proteins content and consequences on yield and other technological properties. (Tables 4 and 5)

Among methods currently used for milk protein analysis, a first group of methods based essentially on the measurement of chemical or structural characteristics of the proteins, such as nitrogen, free $\mathrm{NH}_{3}{ }^{+}$groups (from the $\mathrm{N}$-terminus and basic amino acids), $\mathrm{CO}-\mathrm{NH}$ peptide bonds and aromatic amino acids can be distinguished (Fig. 1). These methods are particularly suitable for the accurate determination of total proteins and the major different nitrogen fractions in milk. They are routinely used for several purposes: animal breeding and feeding, quality based milk payment to the producer and control of the raw material before processing. In this field, rapid indirect spectroscopic method, which trueness is related to the quality and appropriateness of the equations that relies it to true protein based results, is particularly adapted to the analysis of numerous samples.

The second group of methods is based on physicochemical and biological properties of the proteins, such as pH and salt solubility, electric charge at various pH values, molecular mass, hydrophobicity, secondary and tertiary structure and antigenicity, most ultimate detection being based on proper or derived light absorption properties. These methods are used for the separation, 


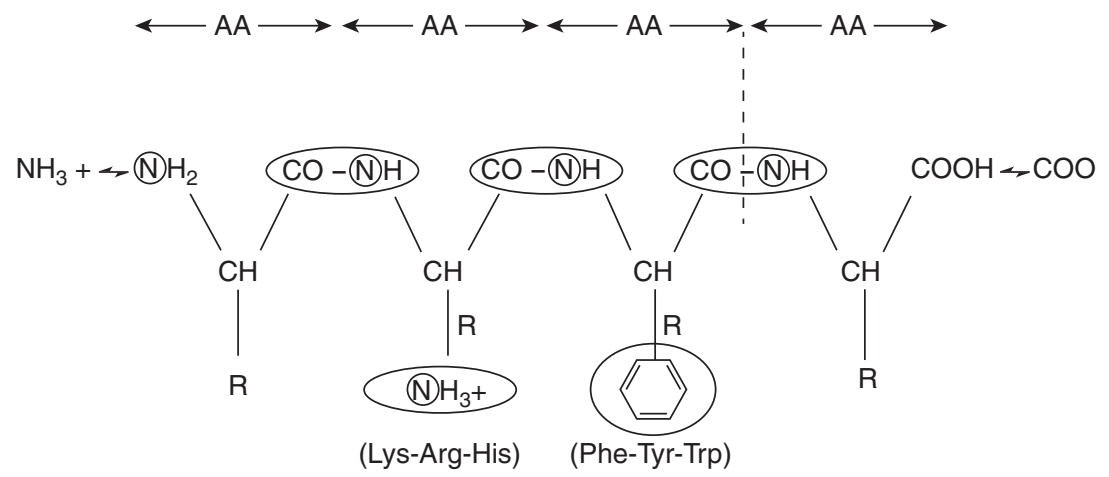

Figure 1 Reactive sites used for quantitative measurement of proteins. AA, amino acids.

identification of the nature of possible modification and quantification of individual proteins in research and for regulatory purposes. By comparison with the previous group of methods, the second ones could progressively emerge in the industrial scope as quality control of the raw material before processing. In the course for constant innovation in dairy products and uncertainty of the origin of procurement, separative-type techniques prove their interest for industrial purpose as there are able to follow the modifications of milk proteins properties (modification due to hydrolysis, aggregation, etc.) and detect improper milk processing quality or trigger adaptation of the technological process.

\section{Definition of Milk Proteins}

Total proteins, caseins, whey proteins and NPN are complex chemical entities that can only be defined by their methods of analysis. These methods belong to the first group of methods cited before or the defining method of the Codex classification. They are based on the fractionation of nitrogenous compounds by the method of Aschaffenburg-Rowland and then on the measurement of nitrogen content of each of these fractions by the Kjeldahl method. Casein $\mathrm{N}$ corresponds to the $\mathrm{N}$ fraction of milk that is insoluble in an acetic acid/sodium acetate buffer at $\mathrm{pH} 4.6$ and $20^{\circ} \mathrm{C}$. Non-casein $\mathrm{N}$ is the soluble fraction under the same conditions. NPN corresponds to the fraction soluble in $12 \%$ trichloroacetic acid (TCA), and whey proteins $\mathrm{N}$ correspond to the difference between non-casein $\mathrm{N}$ and NPN. The protein content is determined by multiplying $\mathrm{N}$ concentration by the internationally accepted conversion factor 6.38 to give the true value for milk proteins.

For applications, these definitions have two important consequences:

1. Because milk contains a significant and variable (3\%-8\%) NPN fraction, it is advisable to distinguish between crude (or total) protein (total $\mathrm{N} \times 6.38$ ) and true protein [(total $\mathrm{N}-\mathrm{NPN}) \times 6.38]$.

2. The conversion factor 6.38 was established a century ago based on the $\mathrm{N}$ content $(15.6 \%)$ of purified acid-precipitated casein. Now, if we consider the primary structure of individual milk proteins, the best estimate for cows' milk total proteins would be 6.35 rather than 6.38 , and would vary between 6.00 and 6.37 for individual proteins. When applying the AschaffenburgRowland procedure, the correct coefficient for caseins, serum protein and NPN would be 6.36, 6.28 and 3.60, respectively.

Quantification of the different nitrogen fractions in milk is standardized at the international level: nitrogen content and crude protein (ISO, 2014), non-protein nitrogen, protein and true protein (ISO, 2016), casein nitrogen (ISO, 2004a, 2004b).

\section{Analysis of Total Proteins}

Three standardized methods are routinely used for quantitative analysis: nitrogen determination by the Kjeldahl' or Dumas' methods, infrared spectroscopy and dye-binding method.

\section{Nitrogen Determination}

\section{Kjeldahl Method}

The principle is to convert quantitatively all the organic and inorganic $\left(\mathrm{NH}_{3} / \mathrm{NH}_{4}{ }^{+}\right.$but not $\left.\mathrm{NO}_{3}\right)$ nitrogen into ammonium sulfate by digestion at $400-420{ }^{\circ} \mathrm{C}$ in a mixture of $\mathrm{K}_{2} \mathrm{SO}_{4} / \mathrm{H}_{2} \mathrm{SO}_{4}$ with a catalyst. The nitrogen concentration is then estimated by acid titration of ammonia released by the distillation of ammonium sulfate in the presence of sodium hydroxide.

To ensure accurate determination, two checks must be performed periodically:

- recovery $(\geq 98 \%)$ of a hard-to-digest compound, such as tryptophan or lysine-HCl, to check the digestion efficiency

- recovery $(\geq 99 \%)$ of a pure ammonium salt (sulfate or oxalate) standard to detect nitrogen loss. 
In addition, it should be kept in mind that milk compounds, particularly fat, consume acid during digestion. Consequently, with high-fat milk, the $\mathrm{K}_{2} \mathrm{SO}_{4}$ will become concentrated in the $\mathrm{H}_{2} \mathrm{SO}_{4}$ and will increase the boiling temperature, leading to nitrogen loss by pyrolytic decomposition of ammonia. Usually, crystallization of the mixture at the end of digestion indicates an excess of acid consumption and volatilization.

\section{Dumas and Related Methods}

Instead of converting nitrogen into a titrable chemical compound, the nitrogen is converted into gas after combustion at a high temperature $\left(>1000{ }^{\circ} \mathrm{C}\right)$ in a furnace. After removing all interfering gases, the nitrogen is measured by thermal conductivity.

Instruments for this method should be calibrated with a pure compound with constant nitrogen content (e.g. aspartic acid) or preferably against the Kjeldahl method. For ultra-high temperature (UHT) milk and fluid milk, repeatability and reproducibility limits are $0.015 \%-0.080 \%$ and $0.041 \%-0.093 \%$, respectively.

\section{Infrared Spectroscopy}

Both the mid-infrared (MIR), from 2.5 to $25.0 \mu \mathrm{m}\left(4000-400 \mathrm{~cm}^{-1}\right)$, and the near-infrared (NIR), from 0.7 to $2.5 \mu \mathrm{m}(14825-$ $4000 \mathrm{~cm}^{-1}$ ), regions are used to analyze milk. The fundamental vibrations of the molecules, which interact with infrared energy, occur mainly in the MIR, whereas absorption in NIR corresponds to harmonic (overtone) and combination frequencies of the fundamental vibrations. Compared with MIR, NIR absorption bands are broader and their intensities are weaker. MIR is used essentially for the analysis of liquid dairy products (milk, cream, whey, etc.), while NIR is for the analysis of either liquid or solid dairy products. Most of the MIR instruments are designed for the analysis of liquid samples by transmission. In some cases (analysis of liquids only), NIR instrument measures the transmitted IR light through a cuvette but it usually measures the diffusely reflected IR light from the surface of solid samples or from the surface of liquids. For MIR milk analysis, the strong absorption of water and a variable and significant light-scattering effect of the milk fat globules must be taken into consideration. To eliminate in part the influence of these two factors, a spectral subtraction of water is needed, and instruments have built-in homogenizers to reduce light scattering. In addition, a short path-length cuvette $(37 \mu \mathrm{m})$ is used.

\section{MIR Analysis}

An infrared spectrum of milk versus water shows several absorption bands that are specific to milk components (Fig. 2 ). At $6.46 \mu \mathrm{m}$ $\left(1550 \mathrm{~cm}^{-1}\right)$, there is a peak corresponding to absorption of the amide II peptide bond: $30 \%$ of the peak originates from the $\mathrm{C}-\mathrm{N}$ stretching vibration and $50 \%$ originates from the $\mathrm{N}-\mathrm{H}$ bending deformation (Fig. 3). In conventional filter instruments, fat, proteins and lactose are measured at their 'specific' wavelengths by reference to close second 'reference' wavelengths, corresponding to minimal absorbances. Even though proteins are the main absorbing components at $6.46 \mu \mathrm{m}$, fat, lactose, phosphate and organic acids with a free carboxylic group $\left(\mathrm{COO}^{-}\right)$may interfere, provided their concentrations are naturally variable in milk and not highly correlated to the protein concentration. To eliminate fat and lactose interferences, inter correction factors are calculated at each measuring wavelength during the calibration step, in order to obtain corrected values for fat, protein and lactose. In addition,

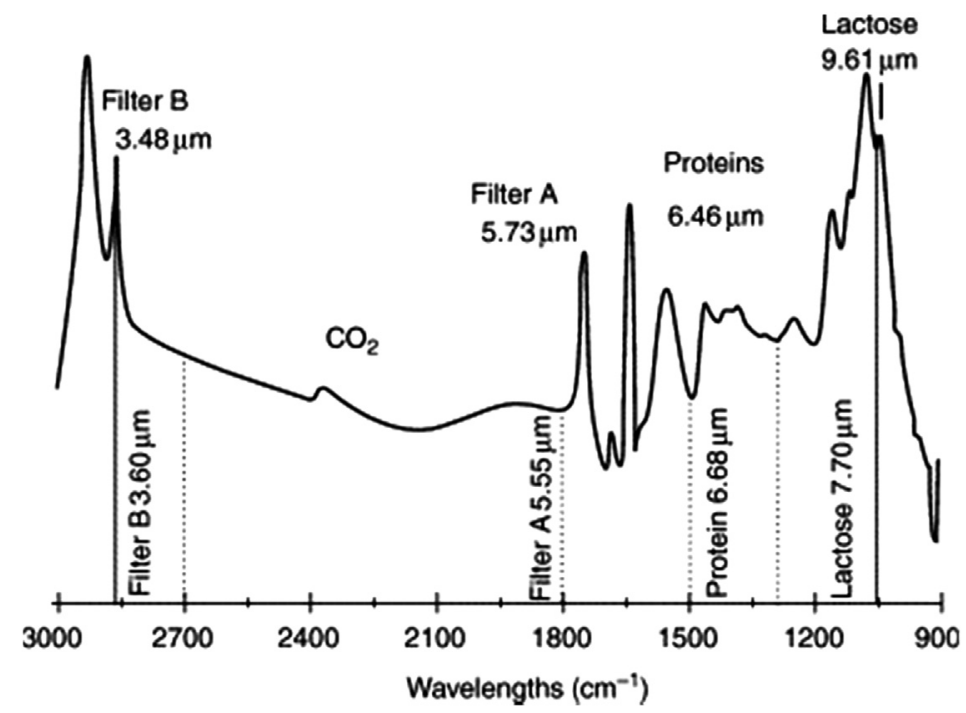

Figure 2 Mid-infrared spectrum obtained in the transmittance mode on a homogenized milk sample compared with water. 


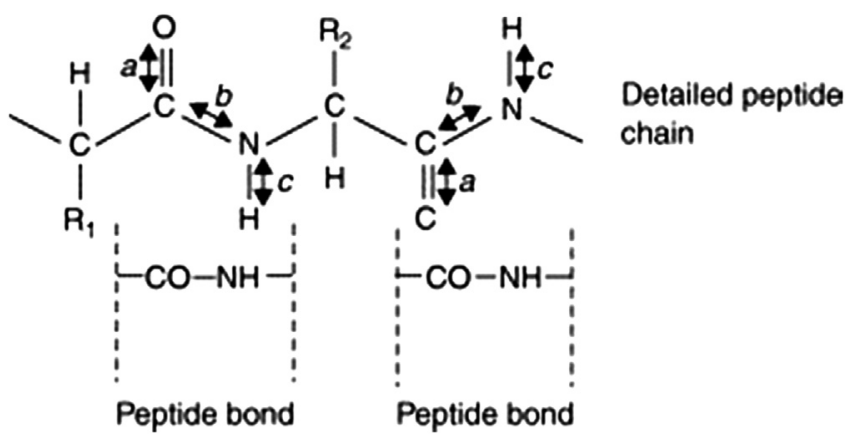

Figure 3 Mid-infrared absorption bands of the peptide bond. a, amide I ( $\mathrm{C}=0$ stretching vibration); $b$, amide II (C-N stretching vibration); $\mathrm{C}$, amide II (N-H bending vibration); arrows, direction of the light-induced dipole; R1, R2, amino acid side chains.

with corrections automatically applied in modern milk analyzers, the variability of NPN (Fig. 4A) and citric acid (Fig. 4B) concentrations can explain most of the differences between infrared and Kjeldahl methods (Fig. 4).

With Fourier transform infrared (FT-IR) spectroscopy, which provides the whole infrared spectrum in a few seconds, it is theoretically possible to include in the calibration all known and unknown factors that may interfere in the measurement. FTIR instruments are now used routinely for milk composition analysis.

\section{NIR Analysis}

Although the polypeptidic chains exhibit specific absorption wavelengths at about $1525 \mathrm{~nm}$ (first harmonic N-H stretching vibration) and $1600 \mathrm{~nm}$ (first harmonic free N-H stretch/amide II combination), two wavelengths near $2050 \mathrm{~nm}$ (N-H stretch/amide II combination) and $2180 \mathrm{~nm}$ (amide A/amide III or first harmonic amide I/amide III combination) are essentially used for milk analysis.

Except for the InfraAlyzer 400 Dairy (Brann and Luebbe, Delaware), which has a built-in homogenizer and a temperaturecontrolled sample cell, no NIR instrument has been especially dedicated to the analysis of milk. Milk can be analyzed either in the transmittance or reflectance mode, and wavelength discrimination is obtained either with filters (InfraAlyzer) or with a grating (NIR System).

One of the most interesting features of NIR spectroscopy is the possibility of connecting an optical fiber probe, to make an in situ measurement.

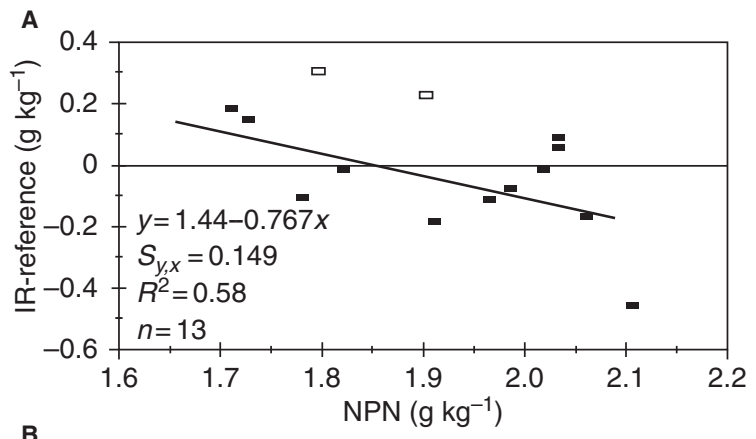

B

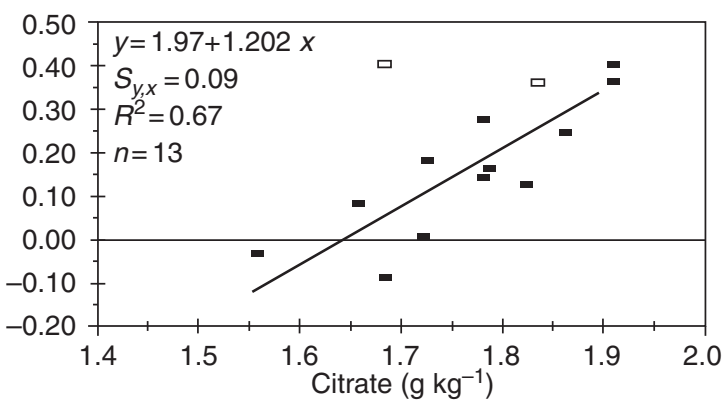

Figure 4 Influence of milk composition (medium molecular mass of fatty acids, non-protein nitrogen (NPN) concentration, citrate concentration) on the differences observed, on the determination of $(A)$ total nitrogen and $(B)$ protein content, between infrared (IR) filter instruments and the reference methods. 
The calibration of NIR instruments follows similar principles to the calibration of MIR concerning the selection of milk samples. Multilinear regression, and more often partial-least-squares (PLS) or even neural networks are used. Often, preliminary treatment of data such as derivations is necessary.

Because of the excellent performance of MIR milk analyzers, very few results on the performances of NIR instruments for milk proteins analysis are available. The repeatability standard deviation is about $0.2 \mathrm{~g} \mathrm{~kg}^{-1}$ and the accuracy standard deviation is in the range of $0.3-0.8 \mathrm{~g} \mathrm{~kg}^{-1}$.

\section{Dye-Binding Methods}

Dye-binding methods are based on the quantitative reaction between ionized groups of proteins and ionized groups of the dye, i.e. sulphonic acid. The amido black method (Alias et al., 1961), which uses CI Acid Black I, is routinely used in different countries. In acid buffer solution ( $\mathrm{pH}$ 2.4), the positive charges on the terminal amino groups and the basic amino acid residues of proteins bind in a stoichiometric interaction with the negative sulphonic groups of the dye, which must be in excess, to form an insoluble complex. In addition, hydrophobic interactions occur between free and bound dye. After centrifugation, the absorbance of the supernatant is measured at about $630 \mathrm{~nm}$. As the quantity of dye bound per unit weight of protein varies with the amino acid composition of the proteins, the proportions of the different proteins in a mixture influence the trueness of the method. Whey proteins bind approximately $27 \%$ more dye than caseins, and the NPN fraction does not bind dye.

\section{Analytical Performances}

When assessing the performance of methods of analysis, technical and economic criteria and accuracy are taken into consideration. Accuracy represents the ability of a method to estimate the true value of an analyte with a known degree of uncertainty. It includes precision, trueness, limit of detection and sensitivity, which have mathematical expressions, as well as specificity:

1. Precision corresponds to the random errors of a measurement. It is expressed as repeatability when measuring conditions are identical and by reproducibility when measurements are made by different laboratories. Their mathematical expressions are the repeatability and the reproducibility standard deviation $\left(s_{r}\right.$ and $\left.s_{R}\right)$ or relative standard deviation $\left(\mathrm{RSD}_{r}\right.$ and $\left.\mathrm{RSD}_{R}\right)$. The maximum differences $(P=.95)$ between two determinations performed under repeatability or reproducibility conditions are given by the repeatability and reproducibility limits $(r$ or $R$ ).

2. Trueness is the systematic differences, or error, between the measured value $(x)$ and the true or reference value $(\gamma)$. It is expressed as the residual standard deviation $\left(s_{\gamma, x}\right)$ of the regression equation, $y=b x+a$, and when the instrument is calibrated, by the mean bias $\left(d_{x-y}\right)$ and the standard deviation $\left(s_{x-y}\right)$ of the difference $x-y$ or by the standard error of prediction (SEP) which is equal to $s_{x-y}$ when $y=x$.

3. Sensitivity is the ratio of the signal increase of the method corresponding to a unit increase in the analyte concentration.

4. The limit of detection is the lowest concentration which can be measured with a known degree of uncertainty.

Precision is a criterion that is common to all methods of analysis. Table 1 gives indicative values of repeatability and reproducibility obtained through international inter-laboratory studies for the reference methods. For the infrared and dye-binding methods, the

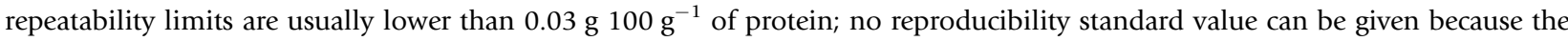
inter-laboratory variability is highly dependent on the procedure used to calibrate the instruments. Lower $R$ values are expected when instruments are calibrated using a common reference material, compared with calibrations made locally with the Kjeldahl method.

Trueness is particularly important for indirect methods of analysis, such as infrared and dye-binding. Table 2 gives examples of trueness values obtained. Dairy laboratories nowadays use fully or semi-automated dedicated instruments that can analyze up to 400 samples $^{-1}$. Repeatability standard deviation is always lower than $0.10 \mathrm{~g} \mathrm{~kg}^{-1}$ milk. However, despite the fact that the entire spectral information is available, similar performances between filter and FT-IR instruments were obtained on a relatively homogeneous population of milk samples, or when calibrations were adjusted regularly to take into account seasonal variations in milk

Table 1 Precision (International Dairy Federation standards) of reference methods for the determination of nitrogen $(\mathrm{N})$ fractions in milk

\begin{tabular}{lll}
\hline$<N$ fraction & Repeatability, $r\left(g 100 g^{-1}\right)$ & Reproducibility, $R\left(g_{100 g^{-1}}\right)$ \\
\hline Total N & 0.0060 & 0.0077 \\
True protein N (direct) & 0.0038 & 0.0092 \\
Caseins N: direct & 0.0064 & 0.0096 \\
Caseins N: indirect & 0.0068 & 0.0113 \\
Soluble N & 0.0043 & 0.0072 \\
Non-protein nitrogen & 0.0025 & 0.0052 \\
\hline
\end{tabular}


Table 2 Examples of trueness values $\left(S_{y, x}\right.$ or $\left.S_{y-x}\right)$ of infrared milk analysers for the analysis of crude proteins, true proteins and caseins of herd or individual cows' or goats' milk samples.

\begin{tabular}{|c|c|c|c|c|c|c|}
\hline \multirow[b]{2}{*}{ Instrument } & \multirow[b]{2}{*}{ Analysis } & \multirow[b]{2}{*}{ Milk } & \multirow[b]{2}{*}{$n$} & \multicolumn{3}{|c|}{$S_{x-y}\left(g \mathrm{~kg}^{-1}\right)$} \\
\hline & & & & Crude proteins & True proteins & Caseins \\
\hline Milko Scan & $\operatorname{MIR}(\mathrm{F})$ & Bulk & 233 & 0.52 & 0.37 & - \\
\hline 605 & & Individual & 117 & 0.48 & - & - \\
\hline Milko Scan & $\operatorname{MIR}(\mathrm{F})$ & Herd & 64 & - & 0.13 & - \\
\hline 4000 & & Individual & 150 & - & 0.36 & - \\
\hline Milko Scan & FT-IR & Herd & 55 & - & 0.15 & - \\
\hline 6000 & & Individual & 112 & - & 0.37 & - \\
\hline $\begin{array}{l}\text { Milko Scan } \\
104\end{array}$ & MIR (F) & $\begin{array}{l}\text { Individual } \\
\text { goat }\end{array}$ & 81 & - & 0.35 & 0.25 \\
\hline $\begin{array}{l}\text { Nicolet } \\
740\end{array}$ & FT-IR & Herd & 73 & 0.38 & - & 0.46 \\
\hline InfraAlyzer & NIR (F) & Individual & 20 & - & - & 0.18 \\
\hline
\end{tabular}

MIR (F): Mid-infrared, FT-IR: Fourier Transform Infrared, NIR (F): Near-infrared.

Table 3 Influence of season on the exactness of measurement of crude and true protein of 163 bulk milks, with filter (Milko Scan 605) and Fourier transform-infrared (Nicolet 740) milk analysers using single or multiple calibrations.

\begin{tabular}{|c|c|c|c|c|c|}
\hline \multirow[b]{2}{*}{ Calibration } & & \multicolumn{2}{|c|}{ Milko scan 605} & \multicolumn{2}{|c|}{ Nicolet 740} \\
\hline & & $d_{x-y}$ & $s_{x-y}$ & $d_{x-y}$ & $s_{x-y}$ \\
\hline \multirow[t]{2}{*}{ Single } & Crude protein & -0.48 & 1.19 & +0.10 & 0.53 \\
\hline & True protein & +0.35 & 1.21 & +0.16 & 0.44 \\
\hline Multiple & Crude protein & 0.00 & 0.48 & 0.00 & 0.46 \\
\hline
\end{tabular}

composition (Table 3). On the other hand, when a single calibration is used throughout the year, far better estimates for both crude protein and true protein are obtained with FT-IR than with a filter instrument (Table 3).

One of the most difficult aspects of analyzing milk proteins by infrared or amido black concerns the calibration.

\section{Analysis of Individual Milk Proteins}

The identification and quantification of individual proteins, variants and isoforms, is needed because their pattern is related to milk production traits, composition, nutritional and technological properties. For example, some variants are related to interesting milk composition (protein, citrate and calcium content) or functional and/or technological properties as illustrated in cheese-making (Marie and Delacroix-Buchet, 1994; Gustavsson et al., 2014; Meza-Nieto et al., 2013; Nuyts-Petit et al., 1997; Delacroix-Buchet et al., 1996). Three techniques i.e. electrophoresis, liquid chromatography and immunochemistry are routinely used for the identification and quantification of individual milk proteins. From a qualitative point of view, none of these techniques is entirely satisfactory and should be considered as complementary depending on the target. From a quantitative point of view, all suffer in particular from the lack of commercial reference proteins of high purity (some are not available at all) and/or of certified reference milk sample. This unavailability leads to trueness bias in the [mass/signal] response factor unless tedious laboratory purification schemes are done, but at the risk also of modifying the secondary and tertiary structures and influencing the measurement. Fat removal of the milk by centrifugation before or after buffer dilution is practically inevitable in all techniques to prevent troubles in the procedure and for reproducible results. Depending on its origin and history, the milk contains more or less large peptides produced by hydrolysis of native caseins by indigenous or microbial proteases which may interfere in the analyses:

- $\gamma 1 \mathrm{f} 29-209, \gamma 2 \mathrm{f} 106-209, \gamma 3$ f108-209, PP5 f1-105 or f1-107, PP8-fast f1-28, PP8-slow f29-105 from $\beta$-CN by the indigenous plasmin protease,

- para- $\kappa$ 1-106 and CMP (or GMP) 106-169 by the action of chymosin or chymosin-like proteases on $\kappa$-casein, or

- $\alpha s_{1-\mathrm{I}}$ 29-199 from $\alpha \mathrm{s}_{1}$-casein by various proteases.

\section{Separative Type Techniques}

"Mapping or profile" separative-type techniques such as HPLC and electrophoresis allow the analysis of whole proteins (and sometimes major degradation products) in only one run whereas the specific and more highly sensitive immunochemical methods is 
limited to one protein at a time and procedures are not yet available for all the proteins. The latest improvements in the chromatographic and electrophoretic material (increase of selectivity and efficiency of separating matrices, multiplication of sensitive and selective detection possibilities such as mass-spectrometry) allows now the simultaneous analysis of casein and whey protein from skim milk with improved resolution of phenotypes (genetic variants and post translational glycosylation and/or phosphorylation). If needed, but at the risk of modifying proteins behavior and ratio, the caseins and whey proteins can also be preliminarily separated by precipitation of the caseins by acidification at $\mathrm{pH} 4.6$ (using acid acetate buffer or $\mathrm{HCl}$ ) or trichloracetic acid (TCA) or perchloric acid (PCA) of different concentrations, by rennet action, by ultrafiltration using specific membranes or by ultracentrifugation. Analysis of caseins alone or in the presence of whey proteins is improved when milk is dispersed in a buffer containing a chaotropic agent (urea or guanidine) that disrupts intra- and intermolecular weak linkages (micelles) and a mercaptan (dithiothreitol-DTT or mercaptoethanol, ME) that disrupts intra- and intermolecular disulphide bonds ( $\alpha \mathrm{s}_{2}$ dimer). Nevertheless, the use of these chemicals may have also deleterious effect on the peak shape, of whey proteins in particular. Accurate quantification needs the determination of proper response coefficients (from proteins of known purity) that could vary widely between proteins and variants at $280 \mathrm{~nm}$ (but not at $214 \mathrm{~nm}$ ).

For simplicity, examples of electrophoretic and chromatographic separations are limited to bovine milk and, unless exceptions, to the more common genotypic variants of the proteins.

In addition to differences in molecular weights, structure, whole hydrophobicity and charge of each protein type, other features, such as genetic amino acid substitutions by basic, acidic or hydrophobic amino acid and post-translational modifications by acidic $N$-acetyl neuraminic acid ( $\kappa$-casein) and/or -phosphate $\left(\kappa-, \alpha \mathrm{s}_{2^{-}}, \alpha \mathrm{s}_{1^{-}}, \beta\right.$-casein), impact more or less the electric charge (and therefore $\mathrm{pI}$ and ionic interaction) and hydrophobicity of the molecules, leading to possible analytical discrimination of variants and isoforms. Table 4 summarizes the general characteristics of the main bovine milk proteins and their variants (Farrell et al., 2004; Caroli et al., 2009).

\section{Slab Gel Electrophoresis}

Proteins can be separated using a vertical or horizontal slab gel system or within a capillary by various electrokinetic techniques, using one or a combination of differences in electric charge, isoelectric point, hydrophobicity and mass ratio.

Table 4 General characteristics of the main bovine milk proteins and their variants

\begin{tabular}{|c|c|c|c|c|c|c|c|}
\hline & & $m g m L-1$ & Variant & Substitution & Molecular weight $(A A)$ & $p l$ & PTM \\
\hline \multirow[t]{15}{*}{ Cns } & $\kappa$ & $2-4$ & A & -Ref- & $\approx 19(169)$ & $5.45-5.77$ & $\mathrm{G}, 1 \mathrm{P}$ \\
\hline & & & B & $\begin{array}{l}\text { Asp148 } \rightarrow \text { Ala } \\
\text { Thr136 } \rightarrow \text { Ile }\end{array}$ & - & $5.3-5.8$ & \\
\hline & & & $\mathrm{E}$ & Ser155 $\rightarrow$ Gly & - & $\ldots$ & \\
\hline & $\alpha \mathrm{s} 2$ & $3-4$ & A & -Ref- & $\approx 23,2(207)$ & $\ldots$ & 10 to $13 \mathrm{P}$ \\
\hline & & & D & 51-59 deleted (1) & $\ldots(198)$ & $\ldots$ & $\ldots$ \\
\hline & $\alpha \mathrm{s} 1$ & $12-15$ & B & -Ref- & $\approx 23,6(199)$ & $4.44-4.76$ & 8 to $9 \mathrm{P}(=\alpha \mathrm{S} 0)$ \\
\hline & & & C & Glu192 $\rightarrow$ Gly & - & $\ldots$ & \\
\hline & $\beta$ & $9-11$ & A2 & -Ref- & $\approx 24,0(209)$ & $4.83-5.07$ & $5 P$ \\
\hline & & & I & Met $93 \rightarrow$ Leu & - & $\ldots$ & \\
\hline & & & $\mathrm{A} 1$ & Pro67 $\rightarrow$ His & - & $\ldots$ & \\
\hline & & & B & Pro67 $\rightarrow$ His & - & - & \\
\hline & & & & Ser122 $\rightarrow$ Arg & & & \\
\hline & & & C & SerP35 $\rightarrow$ Ser & - & $\ldots$ & \\
\hline & & & & Glu37 $\rightarrow$ Lys & & & \\
\hline & & & & Pro67 $\rightarrow$ His & & & \\
\hline \multirow[t]{9}{*}{ WP } & $\alpha-\mathrm{La}$ & $0.6-1.7$ & A & -Ref- & $\approx 14,2(123) \ldots$ & $\ldots$ & \\
\hline & & & B & Gln10 $\rightarrow$ Arg & - & $4.2-4.5$ & \\
\hline & & & D & Gln65 $\rightarrow$ His & - & $\ldots$ & \\
\hline & $\beta-\mathrm{Lg}$ & $2-4$ & B & -Ref- & $\approx 18,3(162)$ & 5.13 & \\
\hline & & & A & Gly80 $\rightarrow$ Asp Ala134 $\rightarrow$ Val & - & 5.13 & \\
\hline & & & C & $\mathrm{G} \ln 75 \rightarrow \mathrm{His}$ & - & $\ldots$ & \\
\hline & BSA & 0.4 & A & - & $\approx 66,4$ & $4.7-4.9$ & \\
\hline & Igs & $0.3-0.6$ & - & - & $\approx 150-1000$ & $5.5-6.8$ & \\
\hline & Lf & $0.02-0.1$ & - & - & $\approx 76,1$ & 8.81 & \\
\hline
\end{tabular}

Cns: caseins, WP: whey proteins; G: glycosylation; P: phosphorylation; PTM: post translational modification; pl: isolectric pH

(1) Glu-Tyr-Ser-Ile-Gly-Ser(P)-Ser(P)-Ser(P)-Glu.

Most data from Farrell et al. (2004) and Caroli et al. (2009). 
In slab gel electrophoresis, after migration, the proteins appear as more or less well-separated bands after being fixed by acid- or alcohol-precipitation and stained. The analytical performance of the quantitative measurements made by densitometry is greatly influenced by the resolution between bands, by the variability in the dye-binding capacity from one protein to another and from one run to another, and by the linearity and sensitivity of the dye (amido black $<$ Coomassie blue $<$ silver stains). The regression coefficient must be determined for each set of analytical conditions. The availability of ultrathin precast minigels with automated electrophoretic equipment, allowing shorter run times, has greatly improved the sensitivity, resolution and speed of slab gel electrophoretic methods for milk proteins.

\section{Urea-PolyAcrylamide Gel Electrophoresis (Urea-PAGE)}

In, In PAGE, proteins migrate mainly according to their charge-to-mass ratio. Alkaline conditions, where proteins are negatively charged, are the most popular protocols for milk proteins. Caseins are better separated in the presence of urea which dissociates intermolecular aggregates, and in the presence of a reducing agent (dithiothreitol) which disrupts the disulphide bonds of as2-casein and $\kappa$-casein. In addition, the use of a polyacrylamide gradient from $8 \%$ to $12.5 \%$ improves the simultaneous analysis of caseins and whey proteins, including some genetic variants and different degrees of phosphorylation. Nevertheless, $\gamma 1$-and $\gamma 3$-caseins produced by plasmin activity are not well resolved from the multiple bands of $\kappa$-casein. The elution order in terms of increasing mobility is bovine serum albumin (BSA), $\kappa$ - and $\gamma$-caseins, $\beta$-casein, $\beta$-lactoglobulin, $\alpha$ s-casein (two bands), $\alpha$ s 1 -casein and $\alpha$-lactalbumin. Whey proteins appear as more diffuse bands than the caseins, which affects their quantification.

\section{Sodium Dodecyl Sulfate - Polyacrylamide Gel Electrophoresis (SDS-PAGE)}

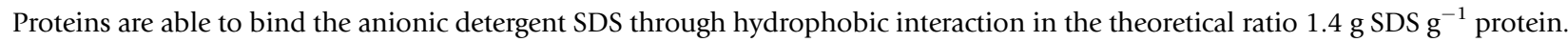
Under these conditions, the charge-to-mass ratio is constant for each protein which migrates according to its decreasing mass due to the sieving effect of the gel. However, the binding capacity of milk proteins differs noticeably from the theoretical values for each protein, which means that the molecular mass with reference to protein standard of known molecular mass cannot be determined. Nevertheless, this method, together with a polyacrylamide gradient, has been successfully used to quantify in a single gel the main proteins in milk (Fig. 5). The technique allows clear separation of all the whey proteins and caseins and some degradation products but genetic variants are not resolved. Due to the shape of the bands and the somewhat poor resolution, quantification is more variable than using urea-PAGE.

A SDS microchip method with laser-induced detection was recently developed for the analysis of whey proteins (Barrios-Romero et al., 2013).

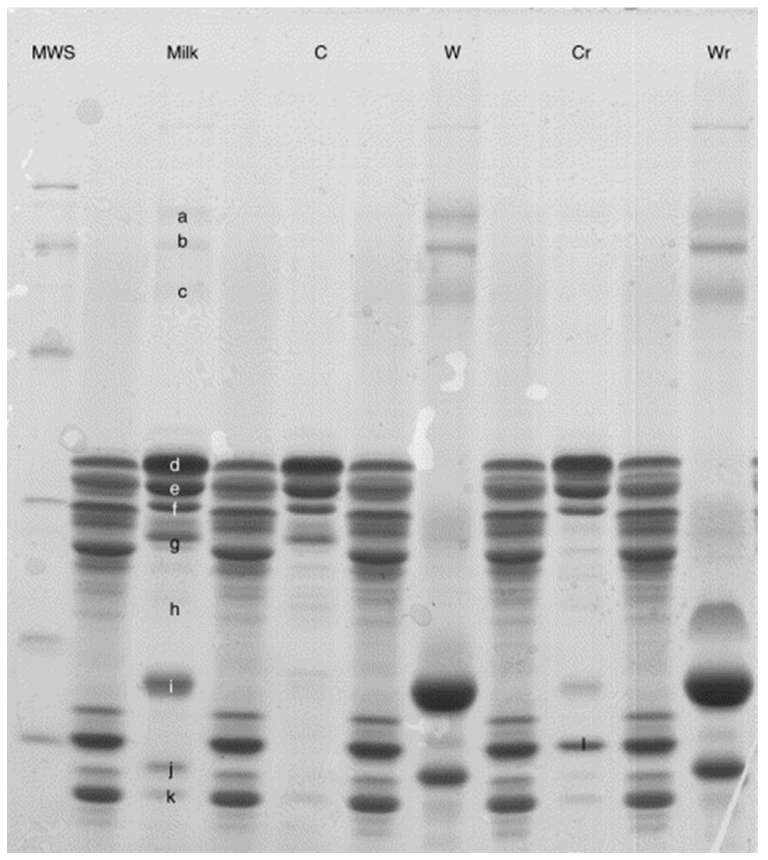

Figure 5 Bovine milk protein analysis by sodium dodecyl sulphate-polyacrylamide gel electrophoresis (SDS-PAGE). MWS, molecular weight standard; C, caseins precipitated at $\mathrm{pH} 4.6$; $\mathrm{W}$, whey proteins soluble at $\mathrm{pH} 4.6$; $\mathrm{Cr}$, para-casein precipitated by rennet hydrolysis; Wr, whey proteins soluble after rennet hydrolysis; a; lactoferrin; b, serum albumin; c, immunoglobulin G; d, as2-casein; e, $\alpha$ s1-casein; $\mathrm{f}, \beta$-casein; $g$, $\kappa$-casein; h, $\gamma 1$-casein; i, $\beta$-lactoglobulin; j, $\alpha$-lactalbumin; $\kappa,(\gamma 2+\gamma 3)$-casein; I, para-к-casein. 


\section{Isoelectrofocusing PAGE (IEF-PAGE)}

Separating proteins according to their isoelectric point allows to identify most of the non-silent genetic variants of the caseins (especially $\beta$-casein) and whey proteins. It is used routinely for the phenotyping of milks. The proteins migrate in a gel containing ampholytes until they meet the zone of the gel corresponding to their isoelectric $\mathrm{pH}$, at which they precipitate. In combination with urea and a reducing agent, caseins are separated in decreasing order of their isoelectric $\mathrm{pH}$, i.e. $\gamma$-casein, $\kappa$-casein $(\mathrm{A}, \mathrm{B}, \mathrm{C})$, $\alpha \mathrm{s}_{2}$-casein (A, D), $\beta$-casein (A1, A2, A3, B, C), $\alpha \mathrm{s}_{1}$-casein (A, B, C). Whey proteins are separated without urea in the following order: $\alpha$-lactalbumin $\mathrm{B}, \beta$-lactoglobulin (A, B). This protocol allows the analysis of caseins and whey proteins together but with no differentiation of $\alpha$-lactalbumin B and $\beta$-lactoglobulin A. IEF remains above all a qualitative method that is currently being replaced by genotyping from DNA extracted from cow's blood.

\section{Two-Dimensional Electrophoresis}

Using a combination of IEF (gel rod, first dimension) and PAGE (slab gel, second dimension), with or without SDS and urea, this high-resolution technique has been successfully applied to identify not only genetic polymorphism but isoforms also, and to study specific protein fractions in complex mixtures, milks of different species (Lindmark-Månsson et al., 2005) and modifications induced by milk heat treatment (Chevalier and Kelly, 2010). Mass spectrometry analysis (MS) of excised spots digested with trypsin and image analyzer are needed for refined identification and quantitation.

\section{Capillary Electrophoresis (CE)}

Capillary electrophoresis (CE) technique is usually considered as having advantages of speed, excellent resolution, simplicity and low operation costs in milk proteins analysis as compared to slab gel electrophoresis. Resolution results from the combined effect of the presence and nature of a coating on the capillary and of the characteristics of the eluting buffer ( $\mathrm{pH}$, ionic strength, modifiers) which determines the importance of the endoelectroosmotic flow and specific electrophoretic mobility of the molecules. Most parameters applicable to milk proteins were developed in the 1990-2000 comparing capillary types and associated samples and running buffers. Currently, one of the most resulting competitive simultaneous separation of milk proteins (Heck et al., 2008) is obtained with milk samples prepared in a pH 8.6 Bis-Tris/3-morpholinopropanesulphonic acid (MOPS) type buffer containing EDTA as calcium chelator, $6 \mathrm{M}$ urea and DTT. Elution is performed using a fused capillary at $45^{\circ} \mathrm{C}$ submitted to $25 \mathrm{kV}$ with an acidic citrate buffer ( $\mathrm{pH} 3$ ) containing 6M urea and a polymeric additive methyl-2-hydroxyethyl cellulose (MHEC). The proteins elute in the following order: $\alpha$-lactalbumin (B, D), $\beta$-lactoglobulin (A, B), $\alpha \mathrm{s}_{2}$-casein (A, D, with separation of 10P-11P (major)-12P), $\alpha \mathrm{s}_{1}$-casein (B, C with differentiation of 7P, 8P and 9P), $\kappa$-casein $\mathrm{E} / \mathrm{A}$ (multiple peaks with one major not glycosylated $\kappa$-casein $1 \mathrm{P}$ but some minors glycosylated multiphosphorylated coeluting with $\beta$-casein), $\beta$-casein (A1, A2, A3, B, C) (Fig. 6). Drawbacks are the elution of micro $\kappa$-casein peaks overlapping with $\beta$-casein. Advantages of CE over slab gel electrophoretic methods include higher sensibility in terms of detection (fluorimetry, mass spectrometry), the possible separation of uncharged silent variants or oppositely charged molecules (para- $\kappa)$, greater automation and smaller quantity of sample. However, good reproducibility depends markedly on the sophistication of the sample preparation and capillary cleaning protocol between injections. Indeed the challenge in CE still remains to limit the adsorption of some proteins on the capillary. Quantification was preferably done at $214 \mathrm{~nm}$ (absorbance proportional to the number of peptides bonds) than $280 \mathrm{~nm}$ (proportional to the aromatic acids content) using peak surfaces. A correction by the retention time is needed in contrast to HPLC and due to the different electrokinetic behavior of

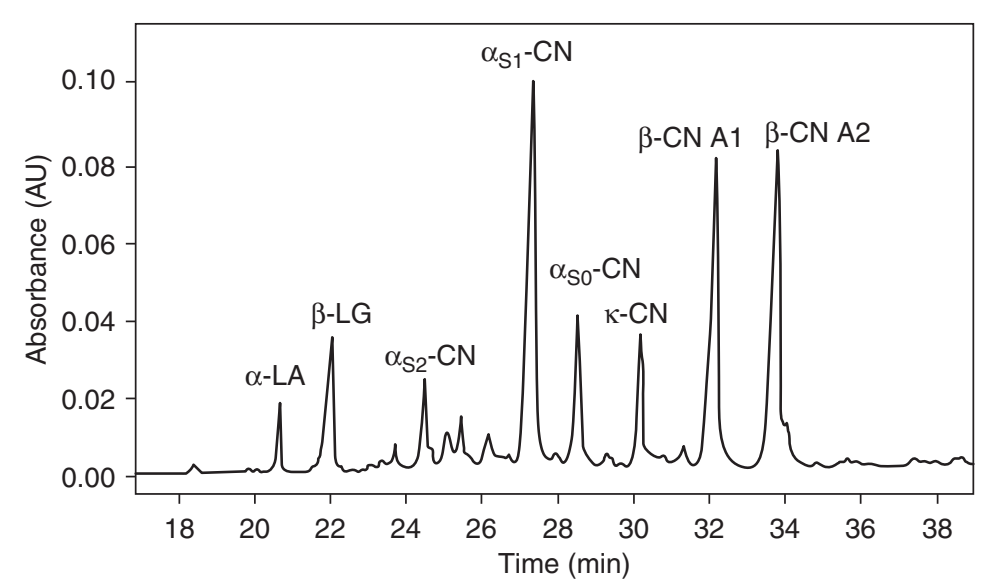

Figure 6 Representative electropherogram of milk proteins using HPCE. Sample buffer: $160 \mathrm{mM}$ Bis-Tris pH 8.6 buffer containing $6 \mathrm{M}$ urea, $67 \mathrm{mM}$ EDTA, $42 \mathrm{mM}$ MOPS and $17 \mathrm{mM}$ DTT and 0.05\% MHEC 3000. Running buffer pH 3: $190 \mathrm{mM}$ citric acid, $20 \mathrm{mM}$ trisodium citrate, $6 \mathrm{M}$ urea, $0.05 \%$ MHEC 3000; deactivated fused silica capillary: $57 \mathrm{~cm} \times 50 \mu \mathrm{m} ; 25 \mathrm{kV} ; 45^{\circ} \mathrm{C}$. Reprint from Heck et al., (2008). 
each protein type does not migrate at the same speed at the detector. Calibration using standard is poorly used in milk protein CE. Individual proteins are expressed as percentage of the total surface of the electropherogram assumed to represent the whole protein content (measured elsewhere), which allows an estimation only as $\mathrm{g} \mathrm{L}^{-1}$ milk level. In addition, CE profiles (as HPLC) contain minor peaks that are not yet assigned. Approximation also is done as it is not taken account of the BSA, IgG and lactoferrin content that can represent a total amount of about $1 \mathrm{mg} \mathrm{mL}^{-1}$ and may vary widely comparing individual cow's (but less in bulk milk).

An in-lab validation of the procedure previously described for the 6 major proteins gave 99\% linearity (increased injected amounts) and a reproducibility that could vary from 1.5 to $15.7 \%$ depending on the protein. Higher variability was observed for $\kappa$ - and $\alpha s_{2}$-cn values due to smaller amounts and multiple peaks, and also for $\alpha$-lactalbumin and $\beta$-lactoglobulin as compared to $\alpha \mathrm{s}_{1}$-and $\beta$-casein. However the variability is inferior to between milks variability.

Some limited results using microfluidic chip capillary electrophoresis show a good correlation with SDS-PAGE results.

\section{Liquid Chromatography}

Ion exchange but mostly reverse-phase chromatography has been used extensively for the analysis and quantification of milk proteins. These techniques are complementary to gel filtration and hydrophobic interaction chromatography, which are particularly suitable for preparative analysis.

\section{Ion-Exchange Chromatography (IEC)}

Due to their charge, proteins are able to bind to a resin exchanger, and to be separated with a NaCl gradient buffer. Nevertheless, IEC does not allow resolving simultaneously all milk proteins. The Mono Q and TSK-DEAE-5PW anion-exchange columns have been reported to separate the four caseins, some of their genetic variants and also according to their degree of phosphorylation. Separation of whey proteins ( $\alpha$-lactalbumin, serum albumin, $\beta$-lactoglobulin A and B) is performed on a Mono Q column. The cationexchange Mono S column is mainly used to separate minor proteins in milk or for some particular separation, such as $\beta$-casein A1, A2 and B variants. Nevertheless the use of IEC is progressively superseded by easier handling and efficient CE or reversephase (RP-HPLC) procedures.

\section{Size Exclusion Chromatography}

The resolution of milk proteins using size-exclusion chromatography is not interesting at all as compared to other recent RP-HPLC procedures but is an interesting tool to highlight heat-treated milks where proteins become aggregated (self-aggregation of $\beta$ lactoglobulin or $\beta$-lactoglobulin-casein aggregates) and thus giving specific profiles.

\section{Reverse-Phase Chromatography (RP-HPLC)}

RP-HPLC took the advantage over the previous liquid chromatography techniques with the improvement of the efficiency and low cost of stationary phase and universality of applications. An example of a typical chromatrogram obtained with milk proteins is presented on Fig. 7.

This technique is based upon hydrophobic interaction between a stationary-phase made of alkyl (C4, C8 or C18) bonded widebore porous silica ( $300 \AA$ ) or polystyrene-divinylbenzene and the proteins in an aqueous solution of low ionic strength. Elution is obtained by increasing the hydrophobicity of the aqueous $0.1 \%$ trifluoroacetic acid (TFA) mobile phase by increasing its content in acetonitrile. The use of short alkyl chains limits the adsorption of proteins onto the phase. Analysis of the milk soluble fraction after laboratory acidification of milk at pH 4.6 (whey protein) or analysis of acid- or rennet-cheese wheys does not present any difficulties. It finds its interest in the detection of milk submitted to heat treatment or adulteration of milk by milk of other species. Other precipitant such as PCA is possible, but TCA partially insolubilizes GMP/CMP. The complete successive resolution of CMP, proteose-peptones (PP), $\alpha$-lactalbumin (overlapping of glycated forms), BSA and $\beta$-lactoglobulin A and B was obtained within 6 min with the following parameters: $\mathrm{C} 8,300 \AA, 5 \mu, 2.1 \times 75 \mathrm{~mm}, 70^{\circ} \mathrm{C}, 214 \mathrm{~nm}$, gradient at $2.5 \mathrm{~mL} \mathrm{~min}^{-1}$ (Sturaro et al., 2016). Precisions lower than $3 \%$ for and LOD of $0.50-0.70 \mu$ injected were observed (Sturaro et al., 2016). Starting from the initial work of Visser et al., (1991) (Visser et al., 1991), the best competitive development for the simultaneous separation and quantification of caseins and whey proteins was achieved in less than $40 \mathrm{~min}$ using the following conditions: a bis-Tris/citrate $\mathrm{pH} 7$ sample buffer with guanidine hydrochloride (instead of urea) and DDT (instead of 2-mercaptoethanol), C8 stationary phase (instead of C18) maintained at $45^{\circ} \mathrm{C}$ (rather than room temperature) and a sophisticated 7 steps-gradient and detection at $214 \mathrm{~nm}$ (instead of $280 \mathrm{~nm}$ ). The following profile was observed: minor glycosylated $(\mathrm{g}) \kappa$-casein $\mathrm{A} / \mathrm{B} / \mathrm{E}$, minor $\mathrm{g} \kappa-\mathrm{A}, \kappa$-casein $(\mathrm{A} / \mathrm{E})$, minor $\mathrm{g}$ $\kappa$-casein $\mathrm{B}, \kappa$-casein $\mathrm{B}, \alpha \mathrm{s}_{2}$-casein $\mathrm{A}(-11 \mathrm{P}$ shouldered with $-12 \mathrm{P}), \alpha \mathrm{s}_{1}$-casein $(\mathrm{B} / \mathrm{C}-8 \mathrm{P}$ shouldered with $-9 \mathrm{P}), \beta$-casein $(\mathrm{B}, \mathrm{C}, \mathrm{A} 1$, A2/I, F), $\alpha$-lactalbumin B, $\beta$-lactoglobulin (D/B, A) (Bonfatti et al., 2008). Some limitation still remains as the expression of plasmin activity in milk leads firstly to $\gamma$-casein fragments from $\beta$-casein that partially co-elute with $\beta$-casein A1 and A2, and secondly induces "noisy peaks" in the $\kappa$-casein/ $\alpha s_{2}$ area. As well, BSA and IgGs would not be detectable in milk sample at 214 nm but they elute before $\beta$-lactoglobulin B and with $\alpha \mathrm{s}_{2}$-Cn respectively. The $\alpha \mathrm{s}_{1-\mathrm{I}} 29-199$ elutes close to $\alpha \mathrm{s}_{1}$-casein A. A better separation of posttranslational phosphorylation may be obtained with slightly different conditions but at the cost of doubling the retention time 


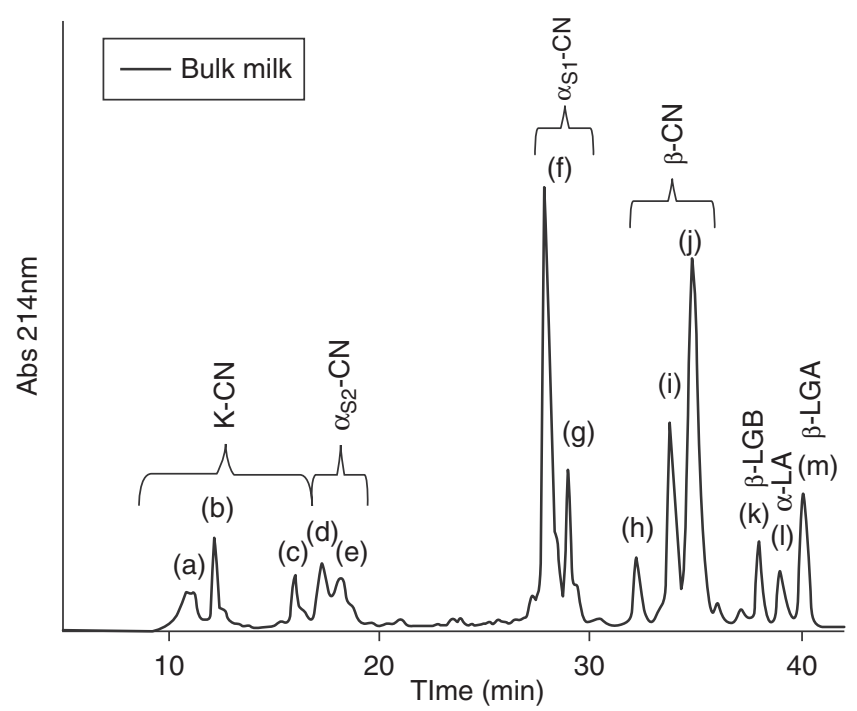

Figure 7 Representative chromatogram of milk proteins (prepared in a $100 \mathrm{mM}$ Bis-Tris pH 7 buffer containing $6 \mathrm{M}$ guanidine $\mathrm{HCl}$ and $10 \mathrm{mM}$ DTT) using RP-HPLC (porous silica C4, $300 \AA, 5 \mu, 250 \times 2 \mathrm{~mm}, 31$ to $45 \%$ acetonitrile in $0.1 \%$ TFA at $35{ }^{\circ} \mathrm{C}$ ). Peaks: (a) $\mathrm{g} \kappa-\mathrm{Cn} \mathrm{A} / \mathrm{B}$, (b) $\kappa-\mathrm{Cn} \mathrm{A}$, (c) $\kappa-\mathrm{Cn}$ B, (d) $\alpha \mathrm{s} 2-\mathrm{Cn} 11 \mathrm{P}$, (e) $\alpha \mathrm{s} 2-\mathrm{Cn} 12 \mathrm{P}$, (f) $\alpha \mathrm{s} 1-\mathrm{Cn} 8 \mathrm{P}$ (g) $\alpha \mathrm{s} 1-\mathrm{Cn} 9 \mathrm{P}$ (h) $\beta$-Cn B (i) $\beta$-Cn A1 (j) $\beta$-Cn A2, (k) $\beta$-Lg B, (i) $\alpha-\operatorname{La~B,~(j)~} \beta$-Lg A. Reprint from Frederiksen et al. (2011).

and with modification of the elution pattern of $\alpha$-lactalbumin and $\beta$-lactoglobulin. In those conditions, chemometric characteristics for individual raw cow's milk of good quality were a full recovery rate, LOD S/N lower than $1 \mu$ g injected for all proteins, and 1 to

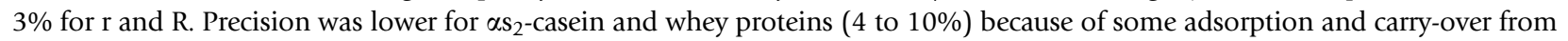
one injection to another, and probably pollution by BSA and immunoglobulins. Precipitation of material on the column may be prevented by diluting the sample in buffer with the eluent A and filtering before injection of a limited volume. In the absence of mass spectrometry, the identification could be ensured using $214 \mathrm{~nm} / 280 \mathrm{~nm}$ surface ratio combined with the normalized secondderivative UV/VIS spectra at the peak. Chemometric, simplicity, robustness (more than 1000 injection per column), automation and richness of information indicate that RP-HPLC protein profiles could be considered as a competing method to the routine Kjeldahl fractionation scheme (and related methods) for the quality control of individual- and bulk raw milk as confirmed by recent exploratory preliminary results (Bonfatti et al., 2016). Nevertheless, the applicability of this protocol to modified or degraded milk should be studied. New emerging silica-based stationary phases such as Core-Shell technology could be interesting as such phase is said doubling or tripling the efficiency as compared to porous silica.

\section{Mass Spectrometry}

Mass spectrometry allows the determination of the exact molecular mass of charged molecules. This technique is particularly adapted for the analysis of proteins and peptides with a high sensitivity and resolution. A mass spectrometer is composed of an ionization source that transfers the molecules to analyze into charged species in a gaseous state, a mass analyzer for the separation of the charged species according to their mass-to-charge ratio and a detector for the precise quantification of each species coming out the analyzer. The ionization source is preferentially an electrospray ionization (ESI) or a matrix-assisted laser desorption ionization (MALDI) source and the analyzer is commonly a quadrupole (Q), a time of flight (TOF) or an orbitrap analyzer. Mass spectrometers are either one-stage instruments (MS) if they are composed of only one analyzer, or multi-stage instruments $\left(\mathrm{MS}^{\mathrm{n}}\right)$ if they combine several analyzers in tandem (for instance $\mathrm{Q}^{3}$ ) or in hybrid (Q-TOF) configurations. $\mathrm{MS}^{\mathrm{n}}$ allow two consecutive stage of molecular mass analysis and by the way are particularly adapted for protein sequencing. For that purpose, the protein is first hydrolyzed by selective proteolytic enzymes (trypsin, chymotrypsin) into a set of peptides. The first mass analyzer separates peptides (precursor ions) based on their mass-to-charge ratio. Each peptide is subsequently fragmented into fragment ions that are characteristic of the precursor ion and are separated and detected with a second mass analyzer.

Due to their large number of ionic groups and their zwitterion character, proteins and peptides give intense signal at relatively low mass-to-charge ratio in negative-ion or positive-ion modes depending on the $\mathrm{pH}$ of the diluting solvent. For analysis, the sample is either incorporated directly in the ionization source of the mass spectrometer or is previously fractionated using a separation technique (HPLC; capillary electrophoresis, CE); the configurations involving the coupling of a separation technique and a mass spectrometer are typically called LC-MS and CE-MS, respectively. With the recent development of the nanospray technology, such configurations simultaneously purify and concentrate the molecule to analyze from a mixture.

Mass spectrometry was advantageously used either to determine the exact mass of the major milk proteins, or to identify many low-abundance proteins in milk (for instance from the milk fat globule membrane, from somatic cells, etc.) or to detect the 
position and nature of mutations and post-translational modifications (phosphorylation, glycosylation) (Fang et al., 2017). Mass spectrometry analysis helped to reveal the extreme complexity of the casein fraction of raw bovine, ovine and caprine milks. It gives a high sensitivity mapping of milks from several breeds of cow and different species. It constitutes a powerful tool to determine the adulteration of buffalo, ovine and caprine milks with bovine milk (Bernardi et al., 2015). Furthermore, the structural modifications induced by technological processing which have an impact on the molecular mass of the milk proteins and peptides are easily tracked by mass spectrometry. A mass increment of $324 \mathrm{Da}$ is indicative of the binding of one lactose molecule on a milk protein or peptide (Leonil et al., 1997). Such modification was detected after heating liquid milks (pasteurized, sterilized) and in freshly prepared milk powders (Oliver, 2011). The deamination and the dephosphorylation of specific amino acids of the caseins as well as protein disulphide bond reshuffling and the formation of covalent non-disulphide bonds between casein molecules were also identified in UHT-treated milks and in milk protein powders by mass spectrometry (Holland et al., 2011; Croguennec et al., 2003). These modifications are continuing at a temperature-dependent rate during the storage of the abovementioned products. Finally, mass spectrometry was successfully used to identify peptides resulting from either the ripening of cheese, the storage of milk products (Meltretter et al., 2008) or the gastrointestinal digestion of dairy products (Barbe et al., 2014; Boutrou et al., 2013).

\section{Immunochemistry}

In spite of their interesting features, such as high specificity and sensitivity, the performance of immunological methods is usually considered to be inadequate technically, commercially and analytically, compared with other techniques, for routine use for the quantitative analysis of milk proteins. For instance, their reproducibility ranges between $2 \%$ and $10 \%$ and, despite their theoretical specificity, their exactness is sometimes questionable. It has been shown, for example that, for the measurement of immunoglobulin $\mathrm{G}$, systematic biases exist between methods, and most discrepancies may occur with respect to the origin of antigens and antibodies used to construct the standard curves and to make measurements. On the other hand, these techniques are considered to be quite suitable for the analysis of individual proteins, either in the field of research or for clinical and regulatory purposes.

Practically all kinds of immunological techniques, using either mono- or polyclonal antibodies were developed to measure the proteins in milk (Table 5). Because milk is an extremely complex biological fluid, the development of accurate and easy-to-perform immunoassays has always been difficult.

\section{Caseins}

Because of their micellar structure, which interferes with the antigen-antibody reaction, and their great susceptibility to hydrolysis by indigenous proteases, such as plasmin or cathepsin $\mathrm{D}$, accurate and straightforward quantitative measurement of caseins in milk is difficult to achieve. Microparticule-enhanced nephelometric immunoassay (MENI) has been applied to a large number of samples (1300 herd milks) for the measurement of $\alpha s_{1}, \beta$ - and $\kappa$-casein (Montagne et al., 1995). This technique has the advantage

Table 5 Examples of immunological methods used for quantitative measurement of proteins in milk

\begin{tabular}{|c|c|c|c|c|c|}
\hline \multicolumn{6}{|c|}{ Performance } \\
\hline Method & Antibody & Proteins & $\begin{array}{l}\text { Working range or limit } \\
\text { of detection }\end{array}$ & $\begin{array}{l}\text { Between-assay } \\
\text { reproducibility }\end{array}$ & Other applications \\
\hline MENI & $\mathrm{pAb}$ & $\begin{array}{l}\alpha_{\mathrm{S}} \text {-Casein } \\
\kappa \text {-Casein } \\
\beta \text {-Lg, } \alpha \text {-La } \\
\lg \mathrm{G}\end{array}$ & $\begin{array}{l}4.0-34.3 \mathrm{~g} \mathrm{I}^{-1} \\
1.3-3.4 \mathrm{~g} \mathrm{I}^{-1} \\
0.6-2.0 \mathrm{~g} \mathrm{I}^{-1} \\
>8 \mu \mathrm{gl}^{-1}\end{array}$ & $\begin{array}{l}1.9-3.4 \% \\
1.9-3.4 \% \\
2-5 \% \\
2.3-10.0 \%\end{array}$ & Whey curd \\
\hline $\begin{array}{l}\text { Competitive } \\
\text { ELISA }\end{array}$ & mAb & $\beta-\mathrm{Lg}$ & $0.03-2.0 \mathrm{ng} \mathrm{mL}^{-1}$ & $<11 \%$ & $\begin{array}{l}\text { Heat treatment (semi-qualitative) cow in goat } \\
(0.03 \%)\end{array}$ \\
\hline Sandwich ELISA & pAb & $\beta-\operatorname{Lg}$ & $>0.02 \mu \mathrm{g} \mathrm{L}^{-1}$ & & Cow in human \\
\hline Inhibition ELISA & $\mathrm{mAb}$ & $\alpha-L a$ & $10-500 \mathrm{ng} \mathrm{mL}^{-1}$ & $11 \%$ & Heat treatment \\
\hline $\begin{array}{l}\text { Competitive } \\
\text { ELISA }\end{array}$ & $\mathrm{pAb}$ & $\alpha-L a$ & $20-1600 \mathrm{ng} \mathrm{mL}^{-1}$ & $2.6-6.4 \%$ & Heat treatment \\
\hline RID & $\mathrm{pAb}$ & $\lg G_{1}$ & $0.2-4 \mathrm{mg} \mathrm{mL}^{-1}$ & $5.1 \%$ & Semi-automated detection of abnormal milks \\
\hline Sandwich ELISA & mAb & Plasmin Plasminogen & $2-100 \mathrm{ng} \mathrm{mL}^{-1}$ & $13 \%$ & - \\
\hline \multirow[t]{3}{*}{ Immunosensor } & $\mathrm{mAb}$ & $\alpha$ s1-casein & $870 \mathrm{ng} / \mathrm{mL}$ & $6.9 \%$ & Heated milks \\
\hline & & $\beta$-casein & $85 \mathrm{ng} / \mathrm{mL}$ & $6.2 \%$ & Cheeses \\
\hline & & $\kappa$-casein & $470 \mathrm{ng} / \mathrm{mL}$ & $5.6 \%$ & \\
\hline Immunosensor & $\mathrm{mAb}$ & $\alpha-\mathrm{La}$ & $1 \mu \mathrm{g} / \mathrm{mL}$ & $1.5-2.4 \%$ & Heat treatment \\
\hline
\end{tabular}

MENI, microparticle-enhanced nephelometric immunoassay; ELISA, enzyme-linked immunosorbent assay; RID, radical immunodiffusion; pAb, polyclonal antibody; mAb, monoclonal antibody; $\beta$-Lg, $\beta$-lactoglobulin; $\alpha$-La, $\alpha$-lactalbumin; IgG, immunoglobulin G. 
that no sample pre-treatment is required. However, it has several drawbacks, such as underestimation of results, a high limit of detection $\left(1 \mu \mathrm{g} \mathrm{mL}^{-1}\right)$ and interference of medium turbidity. More recently, an immunosensor allowing the simultaneous quantification of $\alpha \mathrm{s}_{1^{-}}, \beta$ - and $\kappa$-casein in milk has been developed (Dupont and Muller-Renaud, 2006). This assay consists of a 2-step sandwich strategy, with 2 monoclonal antibodies directed against the $\mathrm{N}$ - and C-terminal extremities of each of the caseins, respectively. This strategy permits only intact caseins to be quantified, and not their degradation products. The technique is fast (10 min/ sample), automated, and has been applied successfully to raw and drinking milks and cheeses.

Because of the significant differences in amino acid sequences, caseins (often $\beta$-casein) are excellent markers for the development of immunoassays enzyme-linked immunoassay (ELISA) or immunoblotting that allow the detection of usually below $1 \%$ of a milk added fraudulently to the milk of a different species, particularly of cows' milk in goats' or ewes' milk (Hurley et al., 2004).

\section{Whey and Minor Proteins}

In contrast to caseins, whey proteins have good antigenic properties, and are not usually hydrolyzed in raw milk. However, during heat treatment, they are susceptible to conformational modifications and to binding to other proteins, and therefore to antigenantibody reaction changes. In fact, advantage has been taken of this property to produce antibodies able to detect, for instance, native or denatured $\alpha$-lactalbumin or $\beta$-lactoglobulin, and to develop immunoassays for the control of the intensity of the heat treatment of milk (Jeanson et al., 1999; Manzo et al., 2015).

Since milk proteins are major food allergens, immunoassays allowing the detection of traces of these proteins into complex food matrices have seen important developments in the last years. Most of the commercially available kits correspond to ELISA-type techniques using mono- or more usually polyclonal antibodies as ligand. They allow a quick quantification of milk proteins in the ppm range. Extraction of the proteins prior to detection may be required in processed food.

In relation to the presence of psychrotrophic bacteria in milk, particularly of Pseudomonas spp. which can produce heat-resistant proteinases responsible for UHT milk gelation, ELISA has been developed to measure the caseino-macropeptide released from the hydrolysis of $\kappa$-casein (Dupont et al., 2007).

Milk hormones, such as prolactin and somatotropin, which can be present in milk, can also be measured by immunoassays (radioimmunoassay and sandwich ELISA).

Immunoassays such as ELISA are nowadays very popular in the food sector. In the near future, more sophisticated techniques like biosensors or even protein arrays will probably receive more interest. A biosensor can be defined as a device that combines a biological recognition mechanism with a transducer, which generates a measurable signal in response to changes in the concentration of a given biomolecule. When studying the interactions between two constituents (e.g. antigen-antibody interaction in the case of immunosensors), one of the components is covalently immobilized to the matrix whereas the other interactant is passed over the sensor in solution. The mass change at the sensor surface, reflecting the progress of the interaction studied, is monitored in real time. The technique, which does not require molecular labels for detection, can measure mass changes down to $10 \mathrm{pg}^{\mathrm{mm}}{ }^{-2}$. Biosensor technology has been used in food analysis since the mid-1990s. During the last years, SPR-based biosensors have been applied to milk proteins for quantifying caseins in milk (Muller-Renaud et al., 2005; Muller-Renaud et al., 2003; Muller-Renaud et al., 2004), following casein-casein (Marchesseau et al., 2002; Thompson et al., 2010) or casein-polysaccharides interactions (Thompson et al., 2010). Furthermore, Johansson et al. examined the potential of SPR-based immunosensors used as probes for exploring the surface of the casein micelle (Johansson et al., 2009).

An antibody microarray is a specific form of protein microarray. A collection of capture antibodies are spotted and fixed on a solid surface, such as glass, plastic, or silicon chip, for the purpose of detecting antigens. An antibody microarray is often used for detecting protein expressions from cell lysates in general research and special biomarkers from serum or urine for diagnosis applications. The great advantage of this technology is to allow a high-throughput simultaneous analysis of thousands of antigen-antibody interactions. Applications related to milk and dairy products are limited and involve the diagnosis of milkrelated pathologies like allergy (Gaudin et al., 2008) or the detection of minor constituents of major biological interest such as cytokines in colostrum (Kverka et al., 2007). More recently, antibody arrays have also been applied to monitor the hydrolysis of caseins during dairy product digestion using collection of monoclonal antibodies of known specificity (Dupont et al., 2010).

\section{Future Trends}

Recently, progress has been made in the differential quantification of casein and whey proteins using infrared spectroscopy and it is probable that separation of these fractions from other milk proteins will no longer be necessary for quantification. Therefore, it can be stated that infrared techniques will find growing applications in the dairy industry.

Immunological techniques will certainly be used more frequently in the near future, especially for applications where their sensitivity and specificity make them unavoidable (minor components, enzymes, hormones). Biosensors have been developed recently for the analysis of dairy products. They are defined as analytical tools or systems consisting of an immobilized biological material in intimate contact with a suitable transducer device which will convert the biochemical signal into a quantifiable electrical signal. Thus, they continue the specificity of biomolecules with the possibility of quantitative or qualitative detection of the biomolecule-analyte interaction by an appropriate, sensitive transducer. They are fast, reliable, sensitive and sometimes automated. Some consist of electrodes that can make in situ measurements. 
Finally, liquid chromatography is a powerful tool, especially when coupled with mass spectrometry, which allows the molecular mass of the molecules separated on the column to be determined. With this technique it has been possible to make major advances in the identification of proteins (including some genetic and post translational variants) in milk and dairy products, interaction between them, effect of treatment (heat, photooxidation ...) and in understanding complex biochemical pathways such as proteolysis during cheese ripening. Capillary electrophoresis is now competing with liquid chromatography. It is now routinely used for the quantification of proteins (whey proteins in particular) in dairy products. However, challenge remains for both LC and CE to better recover proteins and to be able to quantify modifications induced by milk treatments such as heat in particular (Fig. 7).

\section{References}

Alias, C., Ribadeau-Dumas, B., Saint-Lebe, L., 1961. The reaction of amido black with various fractions of milk proteins [Etude de la réaction des protéines du lait avec le "noir amido", application au dosage rapide des matières azotées du lait]. Lait 41, 241-273.

Bonfatti, V., Grigoletto, L., Cecchinato, A., Gallo, L., Carnier, P., 2008. Validation of a new reversed-phase high-performance liquid chromatography method for separation and quantification of bovine milk protein genetic variants. J. Chromatogr. A 1195, 101-106.

Barbe, F., Le Feunteun, S., Remond, D., Menard, 0., Jardin, J., Henry, G., Laroche, B., Dupont, D., 2014. Tracking the in vivo release of bioactive peptides in the gut during digestion: mass spectrometry peptidomic characterization of effluents collected in the gut of dairy matrix fed mini-pigs. Food Res. Int. 63, 147-156.

Barrios-Romero, M.D., Crevillen, A.G., Diez-Masa, J.C., 2013. Development of an SDS-gel electrophoresis method on SU-8 microchips for protein separation with LIF detection: application to the analysis of whey proteins. J. Sep. Sci. 36, 2530-2537.

Bernadi, N., Benetti, G., Hauuett, N.M., Sergi, M., Grotta, L., Marchetti, S., Castellani, F., Martino, G., 2015. A rapid high-performance liquid chromatography-tandem mass spectrometry assay for unambiguous detection of different milk species employed in cheese manufacturing. J. Dairy Sci. 98, 8405-8413.

Bonfatti, V., Degano, L., Menegoz, A., Carnier, P., 2016. Short communication: mid-infrared spectroscopy prediction of fine milk composition and technological properties in Italian simmental. J. Dairy Sci. 99, 8216-8221.

Boutrou, R., Gaudichon, C., Dupont, D., Jardin, J., Airinei, G., Marsset-Baglleri, A., Benamouzig, R., Tome, D., Leonil, J., 2013. Sequential release of milk protein-derived bioactive peptides in the jejunum in healthy humans. Am. J. Clin. Nutr. 97, 1314-1323.

Caroli, A.M., Chessa, S., Erhardt, G.J., 2009. Invited review: milk protein polymorphisms in cattle: effect on animal breeding and human nutrition. J. Dairy Sci. 92, 5335-5352. Chevalier, F., Kelly, A.L., 2010. Proteomic quantification of disulfide-linked polymers in raw and heated bovine milk. J. Agric. Food Chem. 58, $7437-7444$.

Crouguennec, T., Bouhallab, S., Molle, D., O'Kennedy, B.T., Mehra, R., 2003. Stable monomeric intermediate with exposed cys-119 is formed during heat denaturation of betalactoglobulin. Biochem. Biophysical Res. Commun. 301, 465-471.

Delacroix-Buchet, A., Degas, C., Lamberet, G., Vassal, L., 1996. Effect of AA and FF caprine alpha(s1)-casein variants on cheesemaking. Lait 76, $217-241$.

Dupont, D., Muller-Renaud, S., 2006. Quantification of proteins in dairy products using an optical biosensor. J. A0AC Int. 89, 843-848.

Dupont, D., Lugand, D., Rolet-Repecaud, 0., Degelaen, J., 2007. ELISA to detect proteolysis of ultrahigh-temperature milk upon storage. J. Agric. Food Chem. 55, 6857-6862.

Dupont, D., Boutrou, R., Menard, O., Jardin, J., Tanguy, G., Schuck, P., Haab, B.B., Leonil, J., 2010. Heat treatment of milk during powder manufacture increases casein resistance to simulated infant digestion. Food Dig. 1, 28-39.

Fang, Z.H., Bovenhuis, H., Delacroix-Buchet, A., Miranda, G., Biochard, D., Visker, M.H.P.W., Martin, P., 2017. Genetic and nongenetic factors contributing to differences in alpha(s)-casein phosphorylation isoforms and other major milk proteins. J. Dairy Sci. 100, 5564-5577.

Farell, H.M., Jimenez-Flores, R., Bleck, G.T., Brown, E.M., Butler, J.E., Creamer, L.K., Hicks, C.L., Hollar, C.M., Ng-Kwai-hang, K.F., Swaisgood, H.E., 2004. Nomenclature of the proteins of cows' milk - sixth revision. J. Dairy Sci. 87, 1641-1674.

Frederiksen, P.D., Andersen, K.K., Hammershøj, M., Poulsen, H.D., Sørensen, J., Bakman, M., Qvist, K.B., Larsen, L.B., 2011. Composition and effect of blending of noncoagulating, poorly coagulating, and well-coagulating bovine milk from individual Danish Holstein cows. J.Dairy Sci. 94, 4787-4799.

Gaudin, J.C., Rabesona, H., Choiset, Y., Yeretssian, G., Chobnert, J.M., Sakanyan, V., Drouet, M., Haertle, T., 2008. Assessment of the immunoglobulin E-mediated immune response to milk-specific proteins in allergic patients using microarrays. Clin. Exp. Allergy 38, 686-693.

Gustavsson, F., Buitenhuis, A.J., Glantz, M., Stalhammar, H., Lindmark-Mansson, H., Poulsen, N.A., Larsen, L.B., Andren, A., Paulsson, M., 2014. Impact of genetic variants of milk proteins on chymosin-induced gelation properties of milk from individual cows of swedish red dairy cattle. Int. Dairy J. 39, $102-107$.

Heck, J.M.L., Olieman, C., Schennink, A., Van Valenberg, H.J.F., Visker, M.H.P.W., Meuldijk, R.C.R., Van Hooijdonk, A.C.M., 2008. Estimation of variation in concentration, phosphorylation and genetic polymorphism of milk proteins using capillary zone electrophoresis. Int. Dairy J. 18, 548-555.

Holland, J.W., Gupta, R., Deeth, H.C., Alewood, P.F., 2011. Proteomic analysis of temperature-dependent changes in stored UHT milk. J. Agric. Food Chem. 59, 1837-1846.

Hurley, I.P., Ireland, H.E., Coleman, R.C., Williams, J.H.H., 2004. Application of immunological methods for the detection of species adulteration in dairy products. Int. J. Food Sci. Technol. 39, 873-878.

ISO, 2004a. 17997-18001 Milk-Determination of casein-nitrogen content-Part 1: Indirect method.

ISO, 2004b. 17997-18002 Milk-Determination of casein-nitrogen content-Part 2: Direct method.

ISO, 2014. 8968-8971 Milk and milk products-Determination of nitrogen content- Part 1: Kjeldahl principle and crude protein calculation.

ISO, 2016. 8968-8974 Milk and milk products-Determination of nitrogen content-Part 4: Determination of protein and non-protein nitrogen content and true protein content calculation.

Jeanson, S., Dupont, D., Grattard, N., Rolet-repecaud, 0., 1999. Characterization of the heat treatment undergone by milk using two inhibition ELISAs for quantification of native and heat denatured alpha-lactalbumin. J. Agric. Food Chem. 47, 2249-2254.

Johansson, A., Lugand, D., Rolet-Repecaud, O., Molle, D., Delage, M.M., Peltre, G., Marchesseau, S., Leonil, J., Dupont, D., 2009. Epitope characterization of a supramolecular protein assembly with a collection of monoclonal antibodies: the case of casein micelle. Mol. Immunol. 46, 1058-1066.

Kverka, M., Burianova, J., Lodinova-Zadnikova, R., Kocourkova, I., Cinova, J., Tuckova, L., Tlaskalova-Hogenova, H., 2007. Cytokine profiling in human colostrum and milk by protein array. Clin. Chem. 53, 955-962.

Leonil, J., Molle, D., Fauquant, J., Maubois, J.L., Pearce, R.J., Bouhallab, S., 1997. Characterization by ionization mass spectrometry of lactosyl beta-lactoglobulin conjugates formed during heat treatment of milk and whey and identification of one lactose-binding site. J. Dairy Sci. 80, 2270-2281.

Lindmark-Mansson, H., Timgren, A., Alden, G., Paulsson, M., 2005. Two-dimensional gel electrophoresis of proteins and peptides in bovine milk. Int. Dairy J. 15, 111-121. Manzo, C., Nicolai, M.A., Pizzano, R., 2015. Thermal markers arising from changes in the protein component of milk. Food control. 51, 251-255.

Marchesseau, S., Mani, J.C., Martineau, P., Roquet, F., Cuq, J.L., Pugniere, M., 2002. Casein intefractions studied by the surface plasmon resonance technique. J. Dairy Sci. 85, 2711-2721.

Marie, C., Delacroix-Buchet, A., 1994. Comparison of the A and C variants of beta-casein in milk from Tarentaise used in Beaufort-type cheese production. II. Proteolysis and cheese quality (Comparaison des variants $A$ et $C$ de la caséine beta des laits de vaches Tarentaises en modèle fromager de type Beaufort. II Protéolyse et qualité des fromages). Lait 74 , 443-459. 
Meltretter, J., Schmidt, A., Humeny, A., Becker, C.M., Pischetsriedert, M., 2008. Analysis of the peptide profile of milk and its changes during thermal treatment and storage. J. Agric. Food Chem. 56, 2899-2906.

Meza-Nieto, M.A., Gonzalez-Cordova, A.F., Piloni-Martini, J., Vallejo-Cordoba, B., 2013. Effect of beta-lactoglobulin A and B whey protein variants on cheese yield potential of a model milk system. J. Dairy Sci. 96, 6777-6781.

Montagne, P., Cuillere, M.L., Marchal, E., Elbari, N., Montagne, M., Benali, M., Faure, G., Dumeille, J., Humbert, G., Linden, G., Heurtaux, N., Blesche, J., Gosselin, D., Desmares, A., Delahaye, D., 1995. Application of microparticle-enhanced nephelometric immunoassays of alpha-caseins, beta-caseins and kappa-caseins to evaluate quality of milk, from the production to the valorization in cheese industry. Lait 75, 211-237.

Muller-Renaud, S., Dupont, D., Dulieu, P., 2003. Quantification of kappa-casein in milk by an optical immunosensor. Food Agric. Immunol. 15, 265-277.

Muller-Renaud, S.P., Dupont, D., Dulieu, P., 2004. Quantification of beta-casein in milk and cheese using an optical immunosensor. J. Agric. Food Chem. 52, $659-664$.

Muller-renaud, S., Dupont, D., Dulieu, P., 2005. Development of a biosensor immunoassay for the quantification of alpha(S1)-casein in milk. J. Dairy Res, 72, 57-64.

Nutys-Petit, V., Delacroix-Buchet, A., Vassal, L., 1997. Effect of the three most frequent casein haplotypes occurring in the Norman breed used for cheesemaking. Lait 77 , $625-639$.

O'Mahony, J.A., Fox, P.F., Kelly, A.L., 2013. Indigenous enzymes of milk. In: McSweeney, P.L.H., Fox, P.F. (Eds.), Advanced Dairy Chemistry - vol 1A - proteins: basic aspects - 4th edition. Springer, pp. 337-385.

Oliver, C.M., 2011. Insight into the glycation of milk proteins: an ESI- and MALDI-MS perspective (review). Crit. Rev. Food Sci. Nutr. 51, $410-431$.

Reinhardt, T.A., Lippolis, J.D., 2006. Bovine milk fat globule membrane proteome. J. Dairy Res. 73, 406-416.

Sturaro, A., De Marchi, M., Masi, A., Cassandro, M., 2016. Quantification of whey proteins by reversed phase-HPLC and effectiveness of mid-infrared spectroscopy for their rapid prediction in sweet whey. J. Dairy Sci. 99, 68-76.

Thompson, A.K., Singh, H., Dalgleish, D.G., 2010. Use of surface plasmon resonance (SPR) to study the dissociation and polysaccharide binding of casein micelles and caseins. J. Agric. Food Chem. 58, 11962-11968.

Visser, S., Slangen, C., Rollema, H., 1991. Phenotyping of bovine proteins by reversed-phase high-performance liquid chromatography. J. Chromatogr. 548, 361-370. 